\title{
The Role of Organizational Culture of Private Universities on Lecturer Satisfaction and Trust
}

\author{
Furtasan Ali Yusuf \\ Universitas Bina Bangsa, \\ Serang, Indonesia
}

Doi: 10.36941/jesr-2020-0015

Abstract

The culture of private university organizations which tend to be heterogeneous and vary according to the conditions and characteristics of each organization can encourage the growth of the organizational commitment of lecturers and the performance of private universities. However, on the other hand, this organizational culture difference can also hamper the performance of the organizations of each private university in Indonesia to develop the potential of the organization and employee personnel. This study analyzes the influence of organizational culture on the satisfaction and trust of lecturers at private universities in Indonesia. This is based on the consideration that a conducive university organizational culture can trigger the rise of organizational commitment of lecturers. By using analysis of variance to examine the significance and linearity of job satisfaction regression for organizational culture and trust regression for organizational culture, the results indicate a significant and linear relationship in regression testing between job satisfaction for organizational culture and lecturer trust in organizational culture. Practically, this finding indicates the importance of management of private universities to develop organizational culture to realize the vision of subordinates in private universities.

Keywords: organizational culture, private universities, lecturer satisfaction, trust

\section{Introduction}

Culture is a shared value created by a group of people at a certain time. Tangible resources, such as machinery and buildings, are of equal value as intangible resources, such as scientific knowledge and budget management systems, which interact between members of the organization to produce. This is what anthropologists stated as cultural elements. It arises when people reflect their goals, consciously or unconsciously, directly or indirectly. In this cultural system context, Prown (1993) stated that the beliefs of individuals who work in the office, fabrication, purchasing, or that are used together will increase trust and beliefs from the wider community to those owned individually. This implies that culture has a broad and comprehensive meaning that reflects the work, creation, and human initiative, including in organization.

Daft (1995) defines organizational culture as the ability to integrate employee daily activities to achieve planned goals. It can also help organizations adapt to the external environment as a quick and special response (Chang \& Lee, 2007). Schein (2010) defines organizational culture as a pattern of basic assumptions and beliefs shared by members of the organization and is a consistent solution that can work well for a group in dealing with external and internal problems. It can be taught to new 
members as a perception, thinking and feeling in relation to these problems (Williams et al., 2007). Hence, organizational culture contains two meanings. First, the ability to integrate employee daily activities to achieve planned goals and help organizations adapt to the external environment in fast and specific responses. Second, the pattern of assumptions and basic beliefs that are shared by members of the organization and is a consistent solution that can work well for a group in dealing with external and internal problems.

This study seeks to examine the influence of organizational culture on lecturer satisfaction and trust in private universities in Indonesia. This is based on the consideration of Yusuf (2011) that a conducive working environment in university can trigger the rise of organizational commitment of lecturers. Specifically, in the context of examination of this study at private universities in Serang, Indonesia, the organizational culture of private universities in Indonesia generally varies according to the conditions and characteristics of each organization can also encourage the growth of the organizational commitment of lecturers to private universities, especially if the organizational culture private universities in accordance with the wants, needs, vision, mission and personal goals of lecturers. The organizational culture of private universities can accommodate and in accordance with the wants, needs, vision, mission and personal goals of lecturers. These conditions can stimulate the organizational commitment of lecturers to private universities because lecturers can feel that their personal interests are accommodated in the culture of private universities.

\section{Literature Review}

Cultural systems might be considered as products of action, and on the other hand as elements of future action (Furnham, 2006). Hence, culture has a broad scope, which includes the unique configuration of norms, values, beliefs, ways of acting, the best and most important achievement of a person or civilization, emotional sensitivity or intelligence on art and beauty, as well as explicit and implicit behavior patterns obtained and transmitted through symbols.

Regarding organization, experts provide various definitions. Cherrington (1989) for example defines an organization as an open social system. This means that organization refers to a series of interrelated elements, containing resources from the environment where the environment exports useful output products consisting of the patterned activities of a group of people which is relatively stable and events that continue to occur routinely which tends to lead to the goal (Furnham, 2006). For Morgan (1998), the organization as an engine for achieving goals or as a small society with social and cultural structures, or as an organization that breaks through the resource environment (Scott \& Davis, 2007). Jaffee (2001) states that the organization is a tool used by people to coordinate their actions to get something they want or appreciate. Dubrin (2007) stated that an organization is a group of people who work together to achieve a common goal of group. Similarly, it was stated by Shane and von Glinow (2008) that organizations are groups of people who work interdependently for certain purposes. Meanwhile, according to Greenberg and Baron (2003), the organization is a structured social system consisting of groups and individuals who work together to meet agreed targets. From the various definitions it appears that in essence the organization is a collection of people who work together to achieve common goals.

Mullins (2005) mentions a broader set of variables relating to individuals, social, cultural, organizational and environmental factors that influence job satisfaction. The details are in some factors. First, individual factors include personality, education and qualifications, intelligence and ability, age, marital status, work orientation. Second, social factors include relationships with partners, group work and norms, opportunities for interaction, informal organization. Third, cultural factors, including: underlying attitudes, beliefs and values. Fourth, organizational factors include nature and size, formal structure, employee policies and procedures, employee relations, nature of work, technology and work organization, supervision and leadership style, management systems, working conditions. Fifth, environmental factors include economic, social, technical and governmental influences. These various factors all affect job satisfaction of certain individuals in a 
certain set of conditions but not always in other conditions. Various studies of job satisfaction all have validity (Mullins, 2005). From various dimensions, elements or factors can be summarized several important aspects of job satisfaction that can be used as measurement indicators, namely: the work itself, wages / salaries, promotions, work partners, working conditions, challenges, the nature of work, and communication.

Schein as quoted by McShane and Von Glinow (2009) states that organizational culture consists of three main elements. First, artifacts, which consist of stories/legends, rituals/ceremonies, organizational language, and physical structures. Second, shared values, including conscious beliefs and evaluations of what is good and bad, right or wrong. Third, shared assumptions, consisting of unconsciousness either pre-existing perceptions or beliefs, and ideal mental models. This means that organizational culture must include at least artifacts, shared values, and shared assumptions. From this it appears that organizational culture is very closely linked to the elements of togetherness.

Baird et al. (2004) identified three dimensions of organizational culture. First, innovation, namely receptivity and adaptation to change and the willingness to experiment. Second, results orientation, refers to the emphasis of action and results, has the expectation of optimal performance, and competitive. Third, tight versus weak control, leads to suppression of control activities and costs. On the other hand, Brown (1998) proposed 12 indicators to measure organizational culture, namely creativity and innovation, power and conflict, information and communication, regulations, learning, individual, cooperation, trust, conflict, future, loyalty and commitment, and work. This condition confirms the meaning that organizational culture is multidimensional, which is built and consists of many indicators and dimensions. These indicators or dimensions become characteristic of organizational culture in organizations, which distinguishes it from organizational culture in other organizations.

Based on the description above it can be synthesized that organizational culture is a pattern of behavior, assumptions, norms, values, beliefs, and ways of acting that are believed, felt and done and agreed upon by members of the organization as measured by indicators: freedom of action innovation, guaranteed organizational stability, respect for others, results-oriented, attention to details, team-oriented, and aggressiveness to compete. Based on this description, this study proposes the hypothesis that there is a linear and significant relationship between organizational culture and job satisfaction of lecturers and the trust of lecturers working in private universities in universities in Serang, Indonesia.

\section{Method}

This study aims to analyze the influence of organizational culture on the satisfaction and trust of lecturers in private universities in Indonesia. A total of 222 lecturers from 525 lecturer populations in private universities are used as samples for this study.

Operationally, organizational culture is a lecturer's perception of behavior patterns, assumptions, norms, values, beliefs, and ways of acting that are believed, felt, agreed and carried out by lecturers who are projected to be reliable in achieving higher education goals specifically. This variable was reflected in indicators of freedom of innovation, guaranteed organizational stability, respect for others, results-oriented, attention to details, team-oriented, and aggressive competition.

Job satisfaction is defined as a lecturer's assessment of the conditions of his positive and pleasant feelings that arise as a result of his experience of work as a lecturer in tertiary institutions, which includes aspects of the job itself, wages/salaries, promotions, work partners, working conditions, challenges and communication. Trust is defined as the lecturer's assessment of his desire to depend on the leadership of the tertiary institution based on positive expectations of the actions and attentions of the leader of the tertiary institution, which includes indicators: integrity, competence, consistency, loyalty, and openness.

The analytical tool used in this study is linear regression with the SPSS program through analysis of variance for the significance and linearity of job satisfaction regression on organizational 
culture and regression of trust on organizational culture.

\section{Results}

The first test to test the relationship between job satisfaction on organizational culture obtained the results of calculations that showed that to test the significance of the regression of job satisfaction on organizational culture an F-stat. was 129,427, while the F-table value at the error level $(\alpha)=0.01$ was 6 , 75. From these results it is known F-stat. > F-table, so it can be concluded that the regression equation for job satisfaction on organizational culture is very significant. While for the regression linearity test, the F-stat. was 1.330, and the F-table value at the error level $(\alpha)=0.05$ with 47 numerator $\mathrm{dk}$ and 173 denominator $\mathrm{dk}$ 1.44. From these results it is known the value of F-stat. < Ftable, so it can be concluded that the regression equation of job satisfaction variables on organizational culture is linear.

Table 1. Analysis of variance for significance and linearity of job satisfaction for organizational culture

\begin{tabular}{|c|c|c|c|c|c|c|}
\hline \multirow{2}{*}{ Source of Variation } & \multirow{2}{*}{$\mathrm{dk}$} & \multirow{2}{*}{ SS } & \multirow{2}{*}{ ANS } & \multirow{2}{*}{ F-stat. } & \multicolumn{2}{|c|}{ F-table } \\
\hline & & & & & $\alpha=0.05$ & $\alpha=0.01$ \\
\hline Total & 222 & 2260943.00000 & & & & \\
\hline Regression (a) & 1 & 2230612.65315 & & & & \\
\hline Regression (b/a) & 1 & 11234.27181 & 11234.27181 & $129.427^{* *}$ & 3.88 & 6.75 \\
\hline Remainder (S) & 220 & 19096.07504 & 86.80034 & & & \\
\hline $\begin{array}{l}\text { Match (TC) } \\
\text { Error (G) }\end{array}$ & 47 & 5067.15952 & 107.81190 & $1.330^{\mathrm{ns}}$ & 1.44 & 1.66 \\
\hline \multicolumn{7}{|c|}{$\begin{array}{l}\text { ** }=\text { significant }\left(\mathrm{F}_{\mathrm{a}}=129,427>\mathrm{F}_{\mathrm{t}}=6,75\right), \alpha=0.01 \\
\mathrm{~ns}=\text { Linear regression }\left(\mathrm{F}_{\mathrm{a}}=1.330<\mathrm{F}_{\mathrm{t}}=1.44\right), \alpha=0.05 \\
\text { SS }=\text { Sum of squares } \\
\mathrm{dk}=\text { Degrees of Freedom } \\
\text { ANS = average number of regression squares }\end{array}$} \\
\hline
\end{tabular}

The second test to analyze the significance and linearity of trust regression on organizational culture shows the results of the calculation of the significance and linearity of trust regression on organizational culture.

Table 2. Variance analysis table for significance and linearity of trust in trust in organizational culture

\begin{tabular}{|c|c|c|c|c|c|c|}
\hline \multirow{2}{*}{ Source of Variation } & \multirow{2}{*}{$\mathrm{dk}$} & \multirow{2}{*}{ SS } & \multirow{2}{*}{ ANS } & \multirow{2}{*}{ F-hit } & \multicolumn{2}{|c|}{ F-tab } \\
\hline & & & & & $\alpha=0.05$ & $\alpha=0.01$ \\
\hline Total & 222 & 1654824.00000 & & & & \\
\hline Regression (a) & 1 & 1636069.20721 & & & & \\
\hline Regression (b/a) & 1 & 6218.58777 & 6218.58777 & $109,131^{* *}$ & 3.88 & 6.75 \\
\hline Remainder (S) & 220 & 12536.20502 & 56.98275 & & & \\
\hline $\begin{array}{l}\text { Match (TC) } \\
\text { Error (G) }\end{array}$ & 47 & 2836.58140 & 60.35280 & $1,076^{\mathrm{ns}}$ & 1.44 & 1.66 \\
\hline
\end{tabular}

The calculation results show F-stat. 109.131 $>$ F-table at the error rate $(\alpha)=0.01=6.75$, which means the regression equation of trust over organizational culture is very significant. The regression linearity test obtained F- arith $1.076<$ F-table at the error rate $(\alpha)=0.05$ with 47 numerator dk and 103, denominator dk 103 of 1.44. From these results, it is known that the calculated F-stat. $<$ F-table, which means the regression equation of trust variables over organizational culture is linear. 
These findings are theoretically in line with various views on the function of culture in an organization. According to Robbins and Judge (2007), organizational culture has a number of functions. First, setting boundaries, that is, creating clear distinctions between one organization and another. Second, culture provides a sense of identity to members of the organization. Third, culture makes it easy for commitment to something broader than one's personal self-interest. Fourth, improve social system stability. Culture is the social glue that helps unite the organization by providing appropriate standards on what employees must say and do. Fifth, the meaning making mechanism and the controlling mechanism that guides and shapes the attitudes and behavior of the employees. This emphasizes the meaning that organizational culture has certain functions, both for members of the organization and the organization, which can be utilized to achieve organizational goals.

Practically, in order to carry out these functions, the organizational culture must be measurable so that it can be evaluated and fostered. Within this measurement framework, O'Reilly, Chatman and Caldwell (1991) described seven dimensions of organizational culture (McShane \& Von Glinow, 2008). First, innovation, which is characterized by experimenting, looking for opportunities, taking risks, few rules, and low caution. Second, stability, characterized by predictability, security, and orientation to regulations. Third, respect for people, characterized by fairness and tolerance. Fourth, outcome orientation, characterized by action orientation, high expectations, and outcome orientation. Fifth, attention to details which is characterized by accuracy and analytical. Sixth, team orientation is characterized by collaboration and orientation of people. Seventh, aggressiveness, characterized by competitive, low emphasis on social responsibility. This shows that organizational culture includes certain indicators and with or indicators that organizational culture becomes feasible to be measured, evaluated, and then improved and developed.

\section{Conclusion}

This study seeks to examine the influence of organizational culture on lecturer satisfaction and trust in private universities in Indonesia. This is based on the consideration that a conducive university organizational culture can trigger the rise of organizational commitment of lecturers. The results revealed that there is a significant and linear relationship between organizational culture and job satisfaction of lecturers in the college environment. This means that the higher the organizational culture, the higher job satisfaction. This theoretically means that improving organizational culture can significantly increase job satisfaction of lecturers at private universities in Serang, Indonesia. Subsequent findings also reveal a significant and linear influence between organizational culture and trust in lecturers working in private tertiary institutions in Indonesia. This means that the higher the organizational culture, the higher the trust of lecturers. This indicates that improving the quality of organizational culture in this study is proxied by freedom of innovation, guaranteed organizational stability, respect for others, results-oriented, attention to details, team-oriented, and aggressive competition proven empirically to increase the confidence of lecturers working in universities private height.

In the context of the findings of this study, the management of private universities practically needs to develop organizational culture. To realize the vision, followers and their leaders must think, behave and behave in carrying out their duties. For followers to think, behave, and behave in a certain way, leaders need to set guidelines for behavior in the form of norms. The leader collects existing values in the community or develops new values. These values are then used by leaders to motivate and move their followers to achieve the goals set.

The limitation of this study is that it only uses regression analysis based on analysis of variance between organizational culture and job satisfaction as well as organizational culture and trust. Future studies are expected to test longitudinally the influence of organizational culture on this variable by using the indicators of this study.s 


\section{References}

Baird, K. M., Harrison, G. L., \& Reeve, R. C. (2004). Adoption of activity management practices: a note on the extent of adoption and the influence of organizational and cultural factors. Management accounting research, 15(4), 383-399.

Brown, A. D. (1998). Organizational culture (2nd ed). London: Financial Times Management.

Chang, S. C., \& Lee, M. S. (2007). A study on relationship among leadership, organizational culture, the operation of learning organization and employees' job satisfaction. The learning organization, 14(2), 155-185.

Cherrington, D. J. (1989). The Management of Individual and Organizational Performance: Instructor's Manual for Organizational Behavior. Allyn and Bacon.

Daft, R.L. (1995). Organization Theory E Design. St Paul, MN: West Publishing

DuBrin A. J. (2007). Fundamentals of Organizational Behavior. Mason: Thomson South-Western

Furnham, A. (2006). The Psychology of Behavior at Work: The Individual in the Organization. New York: Psychology Press.

Greenberg, J., \& Baron, R. A. (2003). Behaviour in Organisations, eighth (international) edition. Prentice Hall

Jaffee, D. (2001). Organization theory: Tension and change. McGraw-Hill Humanities, Social Sciences \& World Languages.

McShane, S. L., \& Von Glinow, M. A. (2008). Perception and learning in organizations. Organizational behavior, 4, 68-10o.

McShane, S. L., Von Glinow, M. A., \& Radha, S. R. (2009). Organizational Behavior (Skimming and Scanning). New Delhi: Hills Publishing Co. Ltd.

Morgan, G. (1998). Images of organization: The executive edition. Better-Koehler Publishers and SAGE Publications.

Mullins, L. J. (2005). Management and organizational behaviour (7th ed.). New Jersey Prentice Hall.

O'Reilly III, C. A., Chatman, J., \& Caldwell, D. F. (1991). People and organizational culture: A profile comparison approach to assessing person-organization fit. Academy of management journal, 34(3), 487-516.

Prown, J. D. (1993). The truth of material culture: history or fiction?. In History from Things: Essays on Material Culture, edited by Steven D. Lubar and WD Kingery, 1-19. Washington: Smithsonian Institution

Robbins, S. P., \& Judge, T. A. (2007). Organizational Behavior. New Jersey: Person Education.

Schein, E. H. (2010). Organizational culture and leadership (Vol. 2). John Wiley \& Sons.

Scott, W.R., \& Davis, G.F. (2007). Organizations and organizing: Rational, natural, and open system perspectives. Upper Saddle River, NJ: Pearson Prentice Hall.

Williams, E. S., Rondeau, K. V., \& Francescutti, L. H. (2007). Impact of culture on commitment, satisfaction, and extra-role behaviors among Canadian ER physicians. Leadership in Health Services, 20(3), 147-158.

Yusuf, F.A. (2011). Pengaruh Budaya Organisasi, Kepemimpinan, Kepuasan Kerja Dan Kepercayaan Terhadap Komitmen Organisasi Dosen Pada Perguruan Tinggi Swasta Di Kabupaten/Kota Serang Provinsi Banten. (Doctoral Dissertation, Jakarta State University). 